\title{
TEM Characterization of the Recrystallization Behaviour of Warm Rolled Low Carbon Steels Containing Chromium during the Early Stages of Annealing
}

\author{
I. B. TIMOKHINA, J. J. JONAS ${ }^{11}$ and E. V. PERELOMA \\ School of Physics and Materials Engineering, Monash University, VIC 3800, Australia. \\ 1) Department of Metallurgical Engineering, McGill University, Montreal, Quebec, H3A 2B2, Canada.
}

(Received on January 28, 2005; accepted on April 4, 2005)

\begin{abstract}
The early stages of recovery and recrystallisation were studied using transmission electron microscopy in four warm rolled low carbon steels. Three of these contained additions of chromium and of the latter, one was phosphorus and a second boron modified. Addition of the alloying elements led to the formation of both shear and microbands within some of the grains. The progress of recovery in these areas differed from that applicable to the grains containing only microbands. Two types of carbides were present after warm rolling in the steels containing the alloying additions: (i) coarse carbides; and (ii) fine strain-induced particles. The coarse carbides underwent spheroidization and coarsening during annealing. They, on the one hand, accelerated recrystallisation as the particles stimulated nucleation; on the other hand, they retarded it by pinning both the high and low angle grain boundaries. These carbides also influenced the morphology of the recrystallised grains by restraining their growth.
\end{abstract}

KEY WORDS: warm rolling; carbides; shear bands; recovery; recrystallization.

\section{Introduction}

Over the past few decades, warm rolling has been extensively investigated as it decreases production costs in comparison with hot rolling and the required loads are considerably lower than in cold rolling. ${ }^{1-3)}$ As is widely known, good deep drawability requires the presence of a strong $\{111\}$ recrystallisation texture. ${ }^{4,5)}$ In warm rolled materials, the development of such textures is affected by the number of grains containing shear bands. These form at higher strain rates than those pertaining to the bulk material and constitute a form of localised flow within the grains. ${ }^{5)}$ The bands are usually inclined at $20-35^{\circ}$ to the rolling plane ${ }^{6}$ and are most effective at promoting the formation of a strong $\{111\}$ texture after annealing ${ }^{7)}$ when the rate sensitivity is slightly positive during warm rolling.

The present unmodified low carbon steel (hereafter referred to as ELC or extra low carbon became of its low, $0.02 \% \mathrm{C}$, level of carbon) displayed unusually high rate sensitivities in the warm rolling temperature range and therefore contained a low density of shear bands. ${ }^{7)}$ This was associated with a weak $\{111\}$ recrystallisation component and low mean $r$ values. This combination of characteristics has been attributed to the presence of solute carbon during rolling resulting in significant dynamic strain aging (DSA) under warm rolling conditions. ${ }^{8,9}$ )

The negative effects of solute carbon can be reduced by the addition of carbide-forming elements such as chromium and boron. This leads to increases in the number of grains containing shear bands after warm rolling, a change that, in turn, can improve the formability of the steel after annealing. ${ }^{7,10-12)}$ The addition of chromium in particular creates a plateau in the flow stress-temperature curve, thus lowering the rate sensitivity to levels similar to those in highly formable interstitial free (IF) steels.

The formation of carbides in the current materials was recently studied by the present authors. ${ }^{13)}$ This investigation revealed the formation of two types of coarse carbides at the grain boundaries, as well as between and within the microbands and shear bands: cubic $\mathrm{Cr}_{23} \mathrm{C}_{6}$ with a lattice parameter of $a=1.07 \mathrm{~nm}$ and tetragonal $\mathrm{B}_{49} \mathrm{C}_{2}$ with $a=b=0.88$ $\mathrm{nm}, c=0.51 \mathrm{~nm}$. Fine strain-induced cubic $\mathrm{Cr}_{23} \mathrm{C}_{6}$ and orthorhombic $\mathrm{Cr}_{3} \mathrm{C}_{2}$ (with $a=0.55 \mathrm{~nm}, b=0.28 \mathrm{~nm}, c=1.15 \mathrm{~nm}$ ) precipitates were also found in the alloyed steels after warm rolling. These were located within the microbands and at the microband boundaries. ${ }^{13)}$ The formation of these carbides removed carbon from solution. This led to an increase in the number of grains containing shear bands after warm rolling and to strengthening of the $\{111\}$ component.

The presence of particles after deformation can also affect the progress of recovery and recrystallisation during annealing. An increase in the volume fraction of particles retards recovery through their interaction with low angle boundaries. ${ }^{14,15)}$ Moreover, fine strain-induced particles are effective in pinning the subgrain structure and therefore in delaying recovery and recrystallisation. ${ }^{16)}$ It has also been observed that the addition of boron changes the carbide morphology during annealing from elongated to spheri- 
Table 1. Chemical compositions of the steels (wt $\%$ ).

\begin{tabular}{|c|c|c|c|c|c|c|c|}
\hline \multirow{2}{*}{ Steel } & \multicolumn{7}{|c|}{ Element (wt\%) } \\
\cline { 2 - 9 } & $\mathbf{C}$ & $\mathbf{M n}$ & $\mathbf{P}$ & $\mathbf{C r}$ & $\mathbf{B}$ & $\mathbf{A l}$ & $\mathbf{N}$ \\
\hline $\mathbf{E L C}$ & 0.02 & 0.12 & 0.004 & 0.071 & - & 0.048 & 0.0067 \\
\hline $\mathbf{L C}(\mathbf{C r})$ & 0.037 & 0.35 & - & 0.48 & - & 0.036 & 0.0012 \\
\hline $\mathbf{L C}(\mathbf{C r}, \mathbf{B})$ & 0.034 & 0.33 & - & 0.52 & 0.005 & 0.028 & 0.0018 \\
\hline $\mathbf{L C}(\mathbf{C r}, \mathbf{P})$ & 0.039 & 0.32 & 0.04 & 0.5 & - & 0.028 & 0.0024 \\
\hline
\end{tabular}

cal. ${ }^{17)}$

Recrystallised grains are usually formed at nucleation sites such as the initial grain boundaries, deformation bands, deformation twins and precipitates. Nucleation can also take place at the intersection of shear bands and microbands, leading to the formation of a "fragmented" internal structure. ${ }^{18)}$ The aim of the present work was to study the effect of carbide and shear band formation on recovery and recrystallisation during the early stages of annealing. Some attention was also paid to the influence of chromium, phosphorus and boron additions.

\section{Experimental}

Four experimental low carbon steels were investigated, three with additions of about $0.5 \%$ chromium, of which one contained $0.005 \%$ boron and the other $0.04 \%$ phosphorus. The results obtained were compared with the behavior of a commercial extra low carbon $(0.02 \%$ C) ELC steel. The compositions of all four grades are listed in Table 1. The ELC steel was received from Stelco Inc. in Hamilton, Ontario in the form of offcuts from the roughing mill, while the alloyed steels were laboratory grades prepared by Dofasco Inc. in Hamilton, Ontario.

After reheating for $30 \mathrm{~min}$ at $1050^{\circ} \mathrm{C}$, all the samples were warm rolled at $640^{\circ} \mathrm{C}$ and average strain rates of $30 \mathrm{~s}^{-1}$ to reductions of $65 \%$ in a single pass on the EMRCANMET pilot mill in Ottawa, Ontario. Slices of the deformed steels were cut perpendicular to the transverse direction and annealed in an open atmosphere furnace at $710^{\circ} \mathrm{C}$ for periods of $60,120,180,240$ and 300 s to study the recrystallisation behaviour during the early stages of annealing. A thermocouple was attached to the sample to monitor the temperature during annealing. The samples were covered with alumina powder to reduce oxidation.

Transmission electron microscopy was carried out using a Philips CM20 microscope operated at $200 \mathrm{kV}$. Samples were prepared by twin jet electropolishing using a solution of $5 \%$ perchloric acid in methanol at $-30^{\circ} \mathrm{C}$ and an operating voltage of $50 \mathrm{~V}$. Observations were made in both the bright and dark field imaging modes and selected area electron diffraction (SAED) patterns were recorded from areas of interest using an aperture of $1.1 \mu \mathrm{m}$ nominal diameter. The misorientation between subgrains was measured by the microbeam diffraction (MBED) technique using 30 data points. The MBED patterns were obtained using a nominal probe diameter of $15 \mathrm{~nm}$.

Microband and shear band thicknesses were measured by the linear intercept method on 4-5 TEM negatives at a magnification of 11500 times. The sizes of the strain-induced particles in all the alloyed steels and the distances between them were measured from projections onto a $\{111\}$ matrix plane.

\section{Results}

\subsection{TEM Characterization of the Recrystallization Behaviour of the Warm Rolled Steels}

\subsubsection{Deformed Stage}

TEM study of the deformation structure of all the steels after warm rolling at $640^{\circ} \mathrm{C}$ revealed the presence of microbands; these were oriented parallel to the rolling direction and possessed low angles of misorientation $\left(2-3^{\circ}\right)$ (Fig. 1(a)). The average thicknesses of the microbands were similar in the ELC and alloyed steels (Table 2).

Shear bands were present in the steels containing chromium, boron and phosphorus additions. TEM analysis of the samples taken perpendicular to the transverse direction revealed that shear bands were formed at angles of $-35 \pm 10^{\circ}$ with respect to the matrix microbands (Fig. 1(b)). Since these bands nucleate in the grain interiors and then to propagate towards the grain boundaries, ${ }^{19)}$ as a result, many of the grains containing shear bands displayed grain boundary displacements or steps (Fig. 1(b)).

Some orthorhombic $\mathrm{Fe}_{3} \mathrm{C}$ carbides with $a=0.45 \mathrm{~nm}$, $b=0.51$ and $c=0.67 \mathrm{~nm}$ were found in the ELC steel after warm rolling (Fig. 1(c)). These appeared to form at grain and microband boundaries.

Two microstructural features were of particular interest in the alloyed steels: these were the coarse carbides and the fine particles. The coarse carbides were located at the grain boundaries and between/within microbands and shear bands (Figs. 1(a) and 1(b)). By contrast, the fine particles appeared to be formed during warm rolling and were only present within the microbands and at the microband boundaries (Figs. 1(d) and 1(e)). These particles are referred to here as strain-induced particles. The average size of the coarse carbides was $0.16 \pm 0.04 \mu \mathrm{m}$ in length and $0.07 \pm 0.037 \mu \mathrm{m}$ in width. The size distribution of the strain-induced precipitates is shown in Table 3. The $\mathrm{LC}(\mathrm{Cr})$ steel displayed the highest volume fraction of strain-induced precipitates in the matrix (Table 3 ).

All the steels containing alloying elements were characterised by the presence of small amounts of pearlite in the microstructure (Fig. 1(e)).

\subsubsection{Development of the Recovered Structure}

Complex dislocation tangles were observed in the cell walls of the ELC steel after $60 \mathrm{~s}$ of annealing (Fig. 2(a)). These displayed low levels of misorientation $\left(2-3^{\circ}\right)$. However, well-formed subgrains with lower densities of dislocations in their interiors were also found in neighbouring areas (Fig. 2(b)). An increase in the annealing time to $120 \mathrm{~s}$ in the ELC steel led to an increase in the average thickness of the microbands from $0.5 \pm 0.1$ to $0.7 \pm 0.1 \mu \mathrm{m}$ compared with the deformed stage (Table 2).

$\mathrm{Fe}_{3} \mathrm{C}$ carbides were still observed in the ELC steel after $60 \mathrm{~s}$ of annealing. These were found at subgrain (Fig. 2(b)), microband (Fig. 2(c)) and grain boundaries. The carbides at the subgrain boundaries appeared to pin the movement of these boundaries (Fig. 2(b), while the carbides present at the microband or grain boundaries acted as nucleation sites 

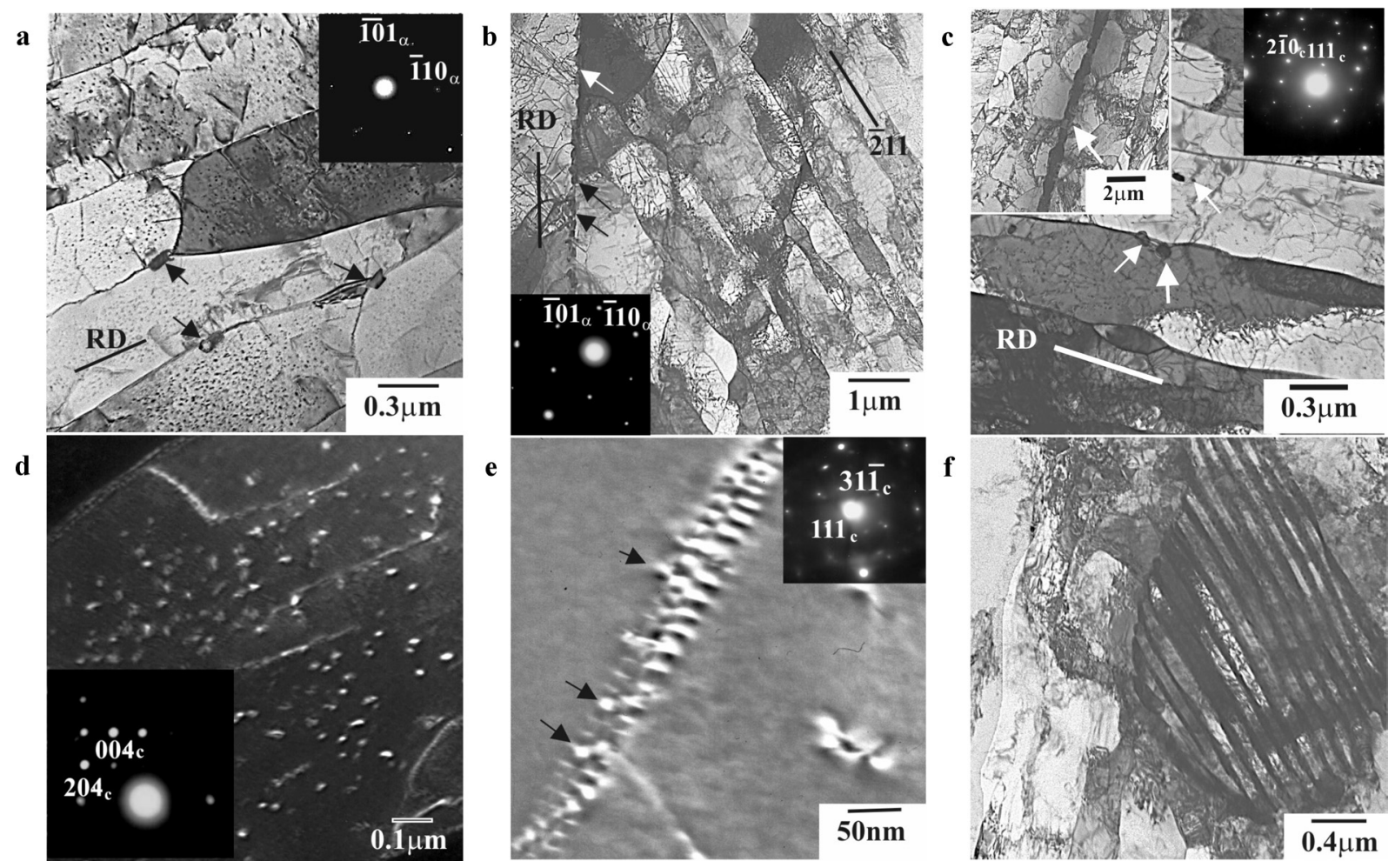

Fig. 1. Bright (a, b, c, e, f) and dark (d) field TEM micrographs of samples warm rolled at $640^{\circ} \mathrm{C}$ : (a) microbands in the $\mathrm{LC}(\mathrm{Cr}, \mathrm{P})$ steel (zone axis is $[1 \overline{1} 1]_{\alpha}$ ), (b) shear bands in the $\mathrm{LC}(\mathrm{Cr})$ steel (zone axis is $[1 \overline{1} 1]_{\alpha}$ ), (c) $\mathrm{Fe}_{3} \mathrm{C}$ carbides at

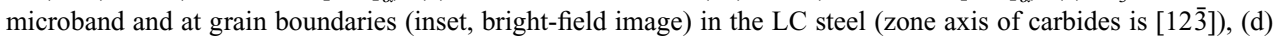
$\mathrm{Cr}_{3} \mathrm{C} 2$ carbides in the $\mathrm{LC}(\mathrm{Cr})$ steel (zone axis is [020] $]_{\mathrm{c}}$, dark-field image from (204) $)_{\mathrm{c}}$, (e) $\mathrm{Cr}_{23} \mathrm{C}_{6}$ carbides in the $\mathrm{LC}(\mathrm{Cr}, \mathrm{P})$ steel (zone axis is $[\overline{1} 2 \overline{1}]_{\mathrm{c}}$ and (f) pearlite in the $\mathrm{LC}(\mathrm{Cr}, \mathrm{B})$ steel. Arrows indicate carbides.

Table 2. Thicknesses of the microbands.

\begin{tabular}{|c|c|c|}
\hline \multirow{2}{*}{ Steel } & \multicolumn{2}{|c|}{ Microband Thickness $(\mu \mathbf{m})$} \\
\cline { 2 - 3 } & Deformed at $640^{\circ} \mathrm{C}$ & $\begin{array}{c}\text { Deformed at } 640^{\circ} \mathrm{C} \text {, annealed at } \\
710^{\circ} \mathrm{C} \text { for } 120 \mathrm{~s}\end{array}$ \\
\hline ELC & $0.52 \pm 0.1$ & $0.7 \pm 0.1$ \\
\hline $\mathbf{L C}(\mathbf{C r})$ & $0.4 \pm 0.1$ & $0.41 \pm 0.1$ \\
\hline $\mathbf{L C}(\mathbf{C r}, \mathbf{B})$ & $0.45 \pm 0.1$ & $0.46 \pm 0.1$ \\
\hline $\mathbf{L C}(\mathbf{C r}, \mathbf{P})$ & $0.5 \pm 0.1$ & $0.5 \pm 0.1$ \\
\hline
\end{tabular}

for new grains (Fig. 2(c)).

Grains containing shear bands were observed in all of the alloyed steels during the TEM investigation. It appeared that the recovery behaviour of grains containing only microbands differed from that of grains containing both microbands and shear bands. The interaction between shear bands and microbands led to the formation of the parallelogram structure displayed in Fig. 3(a). Formation of the parallelogram structure increased the probability of nucleation within this structure. During the early stages of annealing (60-120 s), a cell structure began to develop preferentially in the region where these two microstructural features intersected (Fig. 3(b)). An increase in annealing time led to rearrangement of the dislocations and to the formation of cell walls (Fig. 3(c)). This was followed by the annihilation of dislocations within the cells and the formation of subgrains. The subgrains that formed within the parallelogram structure had average diameters of $0.7 \pm 0.1 \mu \mathrm{m}$ and were more equiaxed than those developed within the microbands (Fig. 4(a)). Moreover, these subgrains were characterised by higher boundary misorientation angles $\left(2-20^{\circ}\right)$ than were those within the microbands (Figs. 4(b) and 4(c)). Analysis of the misorientations associated with $\sim 30$ subgrains indicated that $\sim 35 \%$ of the boundaries had high misorientation levels, i.e. $>15^{\circ}$ (Fig. 4(c)).

Grains without shear bands were also present in the alloyed steels. The standard micromechanisms of recovery were observed in these grains, with the formation of a cell structure through dislocation rearrangement (Fig. 5(a)). This was followed by a process of subgrain formation according to which tangled cell walls are transformed into more regular dislocation networks and the number of dislocations in the cell interiors diminishes (Fig. 5(b)). It was also found that different microband regions displayed different rates of recovery i.e. the formation of subgrains in one regions coincided with the formation of cells in another. Moreover, in contrast to the ELC steel, annealing time had little effect on microband thickness in the alloyed steels (Table 2).

After $60 \mathrm{~s}$ of annealing, coarse $\mathrm{Cr}_{23} \mathrm{C}_{6}$ carbides were found between and within the microbands and shear bands in all the steels containing chromium. When the holding time was increased to $180 \mathrm{~s}$, spheroidization occurred and the volume fraction of carbides increased (Fig. 6(a)). However, in the steel containing the boron addition, spheroidization took place more rapidly than in the others. The carbides then served as nucleation sites for the start of recrystallisation (Fig. 6(b)). The nuclei had average diameters of $0.6 \pm 0.1 \mu \mathrm{m}$ and were characterized by high levels of misorientation with respect to the matrix in most cases. The contributions of the spherical particles as nucleation sites led to the formation of large numbers of nuclei in their vicinities (Fig. 6(c)). On the other hand, the carbides pre- 
Table 3. Precipitate size and distributions.

\begin{tabular}{|c|c|c|c|c|c|}
\hline Steel & $\begin{array}{c}\text { Precipitate } \\
\text { Length } \\
\text { (nm) }\end{array}$ & $\begin{array}{c}\text { Precipitate } \\
\text { width (nm) }\end{array}$ & $\begin{array}{c}\text { Average } \\
\text { effective } \\
\text { spherical } \\
\text { diameter (nm) }\end{array}$ & $\begin{array}{c}\text { Average } \\
\text { Distance } \\
\text { between } \\
\text { Precipitates } \\
\text { (nm) }\end{array}$ & $\begin{array}{c}\text { Precipitate } \\
\text { volume } \\
\text { fraction* }\end{array}$ \\
\hline $\mathbf{L C}(\mathbf{C r})$ & $11 \pm 26$ & $11 \pm 2.6$ & 12.6 & $30 \pm 10$ & 0.13 \\
\hline $\mathbf{L C}(\mathbf{C r}, \mathbf{B})$ & $11 \pm 2.8$ & $7.5 \pm 2.2$ & 10 & $43 \pm 10$ & 0.04 \\
\hline $\mathbf{L C}(\mathbf{C r}, \mathbf{P})$ & $12.8 \pm 3$ & $9.75 \pm 1.5$ & 12 & $40 \pm 11$ & 0.07 \\
\hline
\end{tabular}

*Precipitate volume fraction is deemed to be equal to the area fraction
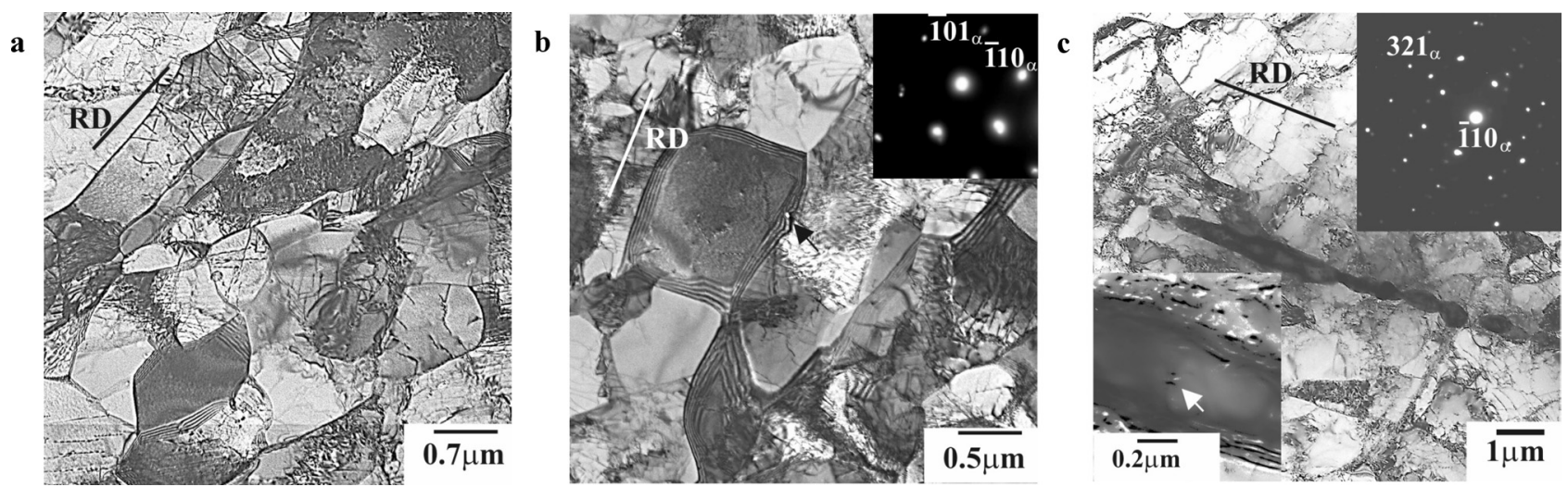

Fig. 2. TEM micrographs of the ELC steel after $60 \mathrm{~s}$ of annealing: (a) formation of cell-structure, (b) formation of subgrains (zone axis is $[111]_{\alpha}$, (c) $\mathrm{Fe}_{3} \mathrm{C}$ carbides along the grain boundary stimulating new grain formation, diffraction pattern (inset) was taken from the new grain with zone axis of $[115]_{\alpha}$ and carbide with zone axis of $[0 \overline{1} 1]_{\mathrm{c}}$ (inset, bright-field image). Arrows indicate the carbides.
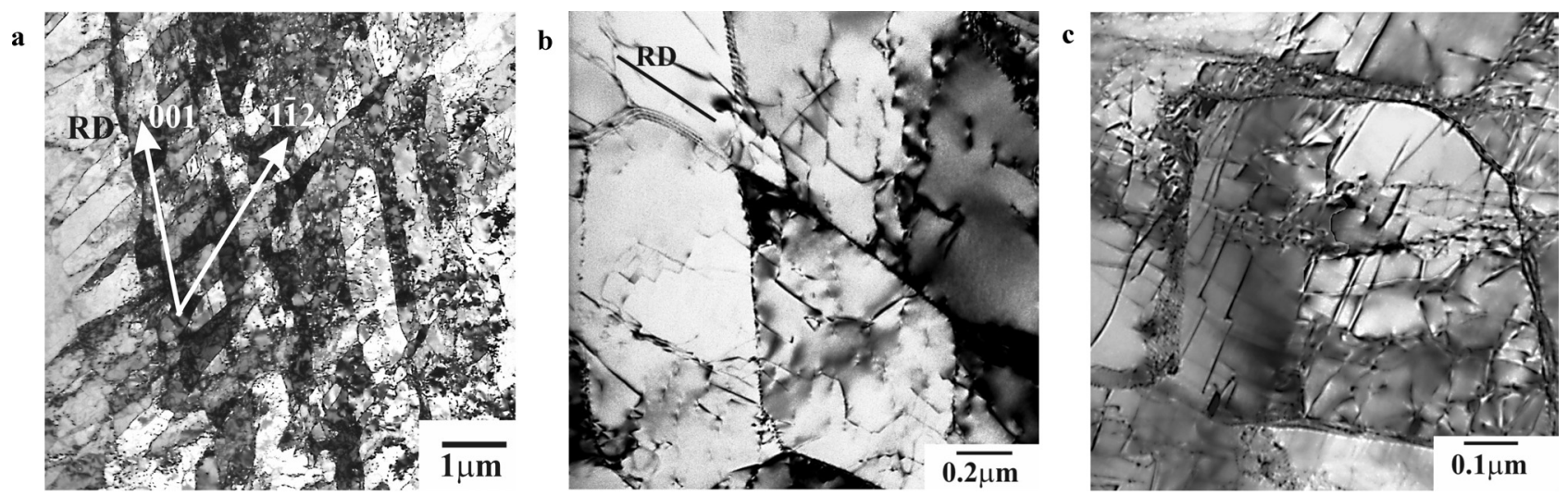

Fig. 3. TEM micrographs of the $\mathrm{LC}(\mathrm{Cr}, \mathrm{P})$ steel after warm rolling at $640^{\circ} \mathrm{C}$ and annealing for $120 \mathrm{~s}$ at $710^{\circ} \mathrm{C}$ : (a) and (b) formation of the parallelogram structure, zone axis is $[110]_{\alpha}$, microbands are parallel to $(001)_{\alpha}$, shear bands are parallel to $(1 \overline{1} 2)_{\alpha},(\mathrm{c})$ development of dislocation cells within the parallelogram structure.

sent at the grain boundaries of the nuclei pinned these boundaries (Fig. 6(d)). Some carbides were also found at subgrain boundaries during recovery (Fig. 6(e)).

It was observed that the volume fraction and size of the strain-induced particles present within the microbands and at the microband boundaries remained approximately constant during annealing. These particles prevented dislocation movement within the microbands during formation of the cell structure while recovery was taking place (Fig. $6(f))$.

\subsubsection{Development of the Recrystallised Structure}

Recrystallised grains exhibiting high angles of misorientation with respect to the matrix were already present in the ELC steel after $60 \mathrm{~s}$ (Fig. 7(a)). These grains were of equiaxed shape and had a minimum grain size of $3 \mu \mathrm{m}$, while the average size was $7.5 \pm 0.5 \mu \mathrm{m}$ (Fig. 7(a)).

The recrystallised grains in the alloyed steels only appeared after $180 \mathrm{~s}$. The grains that formed at the microbands or shear bands were elongated along either the microband (Fig. 7(b)) or shear band direction (Fig. 7(c)). The shapes of some of the recrystallised grains indicated that they formed along the microband clusters (Fig. 7(b)). The average recrystallised grain size after $180 \mathrm{~s}$ of annealing was $10.1 \pm 1$ for the $\mathrm{LC}(\mathrm{Cr})$ steel, $10.4 \pm 1$ for the $\mathrm{LC}(\mathrm{Cr}, \mathrm{P})$ steel and $12.5 \pm 1.5 \mu \mathrm{m}$ for the $\mathrm{LC}(\mathrm{Cr}, \mathrm{B})$ steel with an average thickness of the elongated grains of $3 \pm 1 \mu \mathrm{m}$. The boundaries of the recrystallised grains formed at shear bands were characterised by curved shapes in contrast to those formed at the microbands (Fig. 7(d)). Moreover, such recrystallised grains were able to suppress the recovery process in the areas adjacent to them. 
Furthermore, two recrystallising grains can gradually consume the recovered area between them if the width of this area is less than that of one of the recrystallising grains (Fig. 7(e)).

TEM analysis revealed the presence of coarse carbides within the recrystallised grains and at the grain boundaries (Figs. 7(c), 7(e), Fig. 8(a)). These carbides were larger $(0.3 \pm 0.04 \mu \mathrm{m}$ in width and $0.6 \pm 0.05 \mu \mathrm{m}$ in length) than those found after deformation or present during the recovery process (Fig. 8(a)). The coarse particles observed within the recrystallised grains appeared to be the ones previously located at the microband and shear band boundaries. These carbides thus acted as nucleation sites (Fig. 6(d)). The carbides present at the recrystallised grain boundaries not only acted as nucleation sites but also affected the process of growth of the new grains (Fig. 8(b)).

Strain-induced particles were found within the recrys-
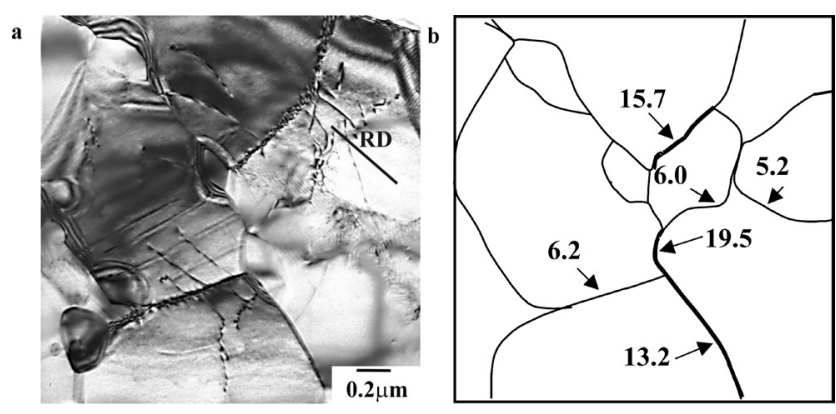

c

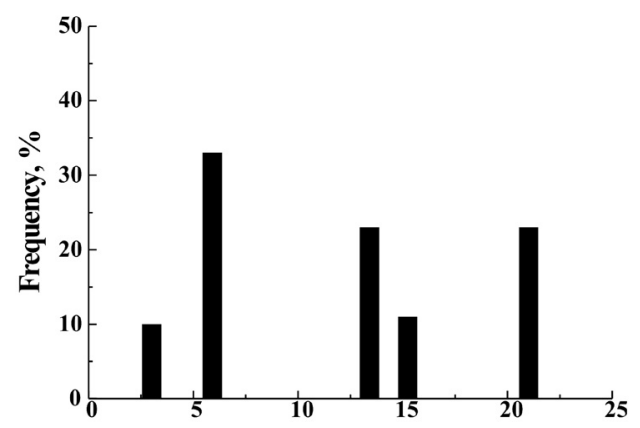

Misorientation,

Fig. 4. TEM micrograph of the subgrains (a), schematic diagram of their misorientations (b), and summary of distribution of misorientations (c) in the $\mathrm{LC}(\mathrm{Cr}, \mathrm{P})$ steel after $180 \mathrm{~s}$ of annealing. tallised grains. The latter appeared to inherit the volume fractions and sizes of the strain-induced particles within the microbands (Fig. 8(c)).

\subsubsection{Nucleation at Pearlite during the Early Stages of Annealing}

The pearlite present in the alloyed steels appeared to decompose after $\sim 180 \mathrm{~s}$ of annealing with the formation of spherical $\mathrm{Fe}_{3} \mathrm{C}$ carbides and ferrite (Fig. 9(a)) in the $\mathrm{LC}(\mathrm{Cr})$ and $\mathrm{LC}(\mathrm{Cr}, \mathrm{P})$ steels. In the $\mathrm{LC}(\mathrm{Cr}, \mathrm{B})$ steel, decomposition took place even more quickly and was already well under way after $120 \mathrm{~s}$. The spherical carbides were aligned along the previous lamella lines. The average diameter of these carbides was $0.8 \pm 0.03 \mu \mathrm{m}$. These spheroids then acted as nucleation sites for new grains with high angles of misorientation (Fig. 9(b)). The recrystallisation process in this case was similar to that observed next to the chromium carbides. Since the region containing decomposed pearlite was characterized by a large number of carbides, many nuclei were formed in this area (Fig. 9(c)). Moreover, some of the carbides seemed to generate multiple nuclei i.e., they acted as nucleation sites for two or more nuclei (Fig. 9(d)).

The recrystallised grains formed at the spherical carbides emanating from the pearlite were of equiaxed shape and were bounded by high angles of misorientation (Fig. 9(e)).

\section{Discussion}

TEM study of the early stages of annealing revealed two important aspects of recovery and recrystallisation in the present materials: (i) the effect of shear band formation and (ii) the effect of particles. These effects will now be considered in greater detail.

\subsection{Effect of Substructure and Carbides on Recovery}

Examination of the samples revealed the presence of grains with two different types of internal structures: (i) those containing microbands and shear bands and (ii) grains containing only microbands. The formation of shear bands in the alloyed steels at angles of $\sim 35^{\circ}$ with respect to the matrix microbands led to the development of the parallelogram structure in the areas of their interaction. This structure increased the potential nucleation area as well as the probability of nucleus formation. The parallelogram structure also increased the local stored energy and thus the $\mathbf{a}$

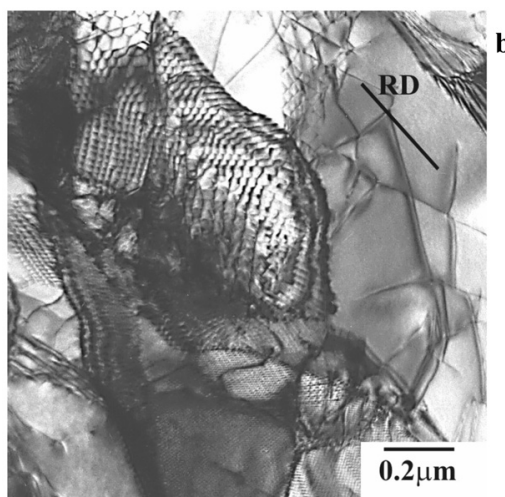

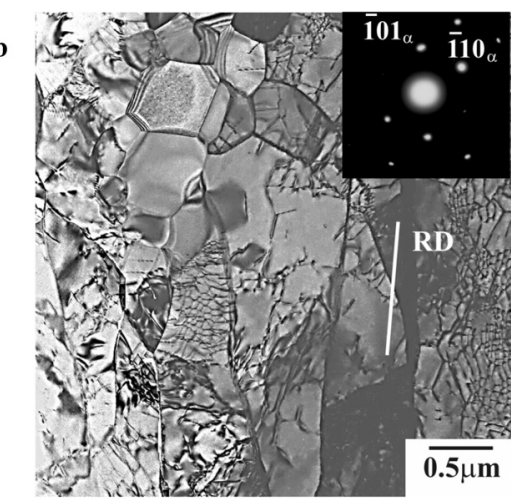

Fig. 5. TEM micrographs of the $\mathrm{LC}(\mathrm{Cr})$ steel after warm rolling at $640^{\circ} \mathrm{C}$ and annealing for $120 \mathrm{~s}$ at $710^{\circ} \mathrm{C}$ : (a) formation of cells, (b) cells and subgrains with zone axis of $[111]_{\alpha}$. 

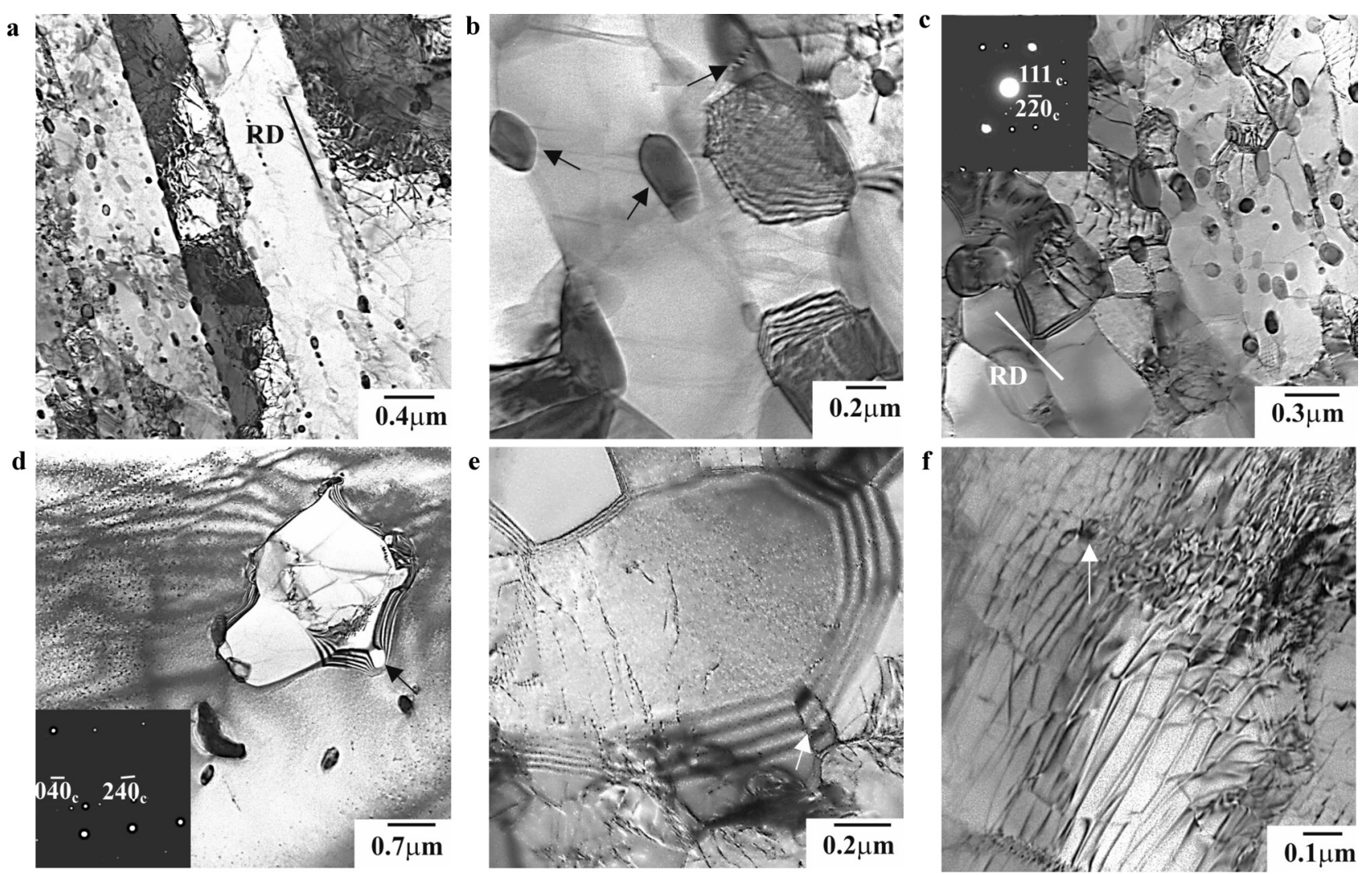

Fig. 6. Micrographs of the carbides found in the $\mathrm{LC}(\mathrm{Cr}, \mathrm{B})(\mathrm{a}), \mathrm{LC}(\mathrm{Cr})(\mathrm{b}, \mathrm{c}, \mathrm{d}, \mathrm{e})$ and $\mathrm{LC}(\mathrm{Cr}, \mathrm{P})$ (f) steels after $180 \mathrm{~s}(\mathrm{a}$, $\mathrm{b}, \mathrm{c}, \mathrm{e}), 300 \mathrm{~s}$ (d) and $120 \mathrm{~s}$ (f) of annealing, diffraction pattern (inset, c) of $\mathrm{Cr}_{23} \mathrm{C}_{6}$ carbide, zone axis is $[22 \overline{4}]_{\mathrm{c}}$ $(a=1.07 \mathrm{~nm})$ and matrix, zone axis is $[111]_{\alpha}$; and diffraction pattern (inset, d) of carbide, zone axis is $[00 \overline{8}]_{\mathrm{c}}$ and new grain, zone axis is $[115]_{\alpha}$. Arrows indicate carbides.
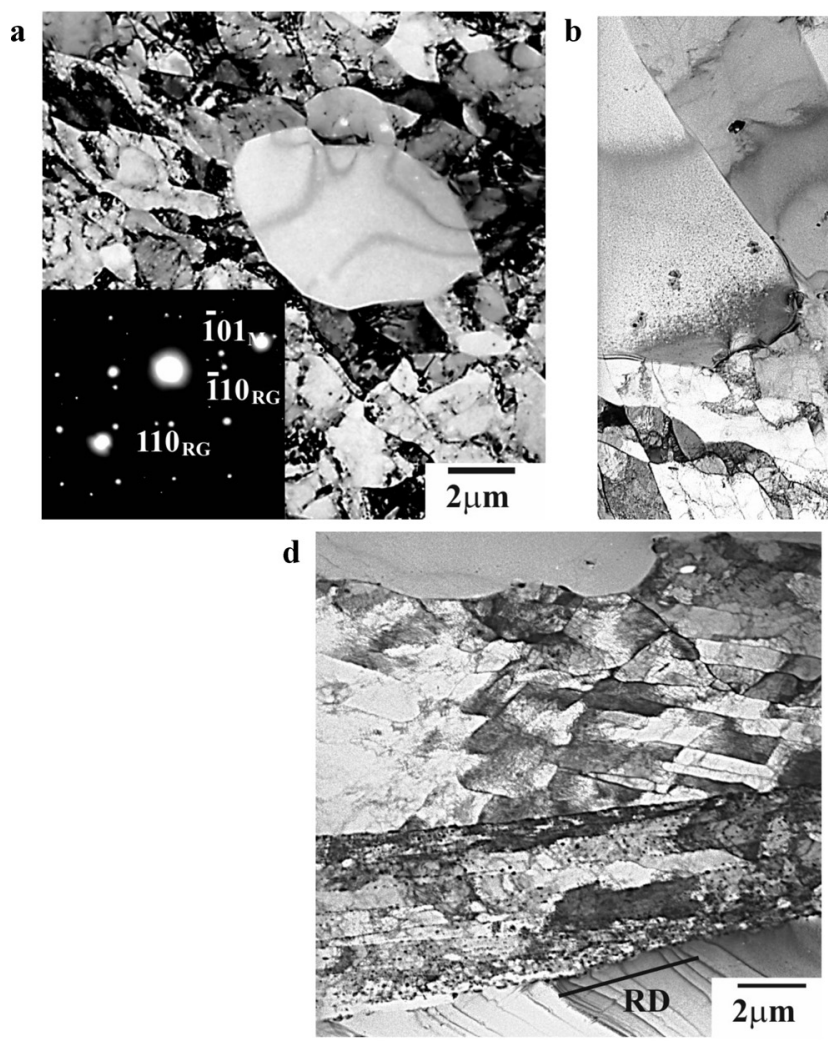
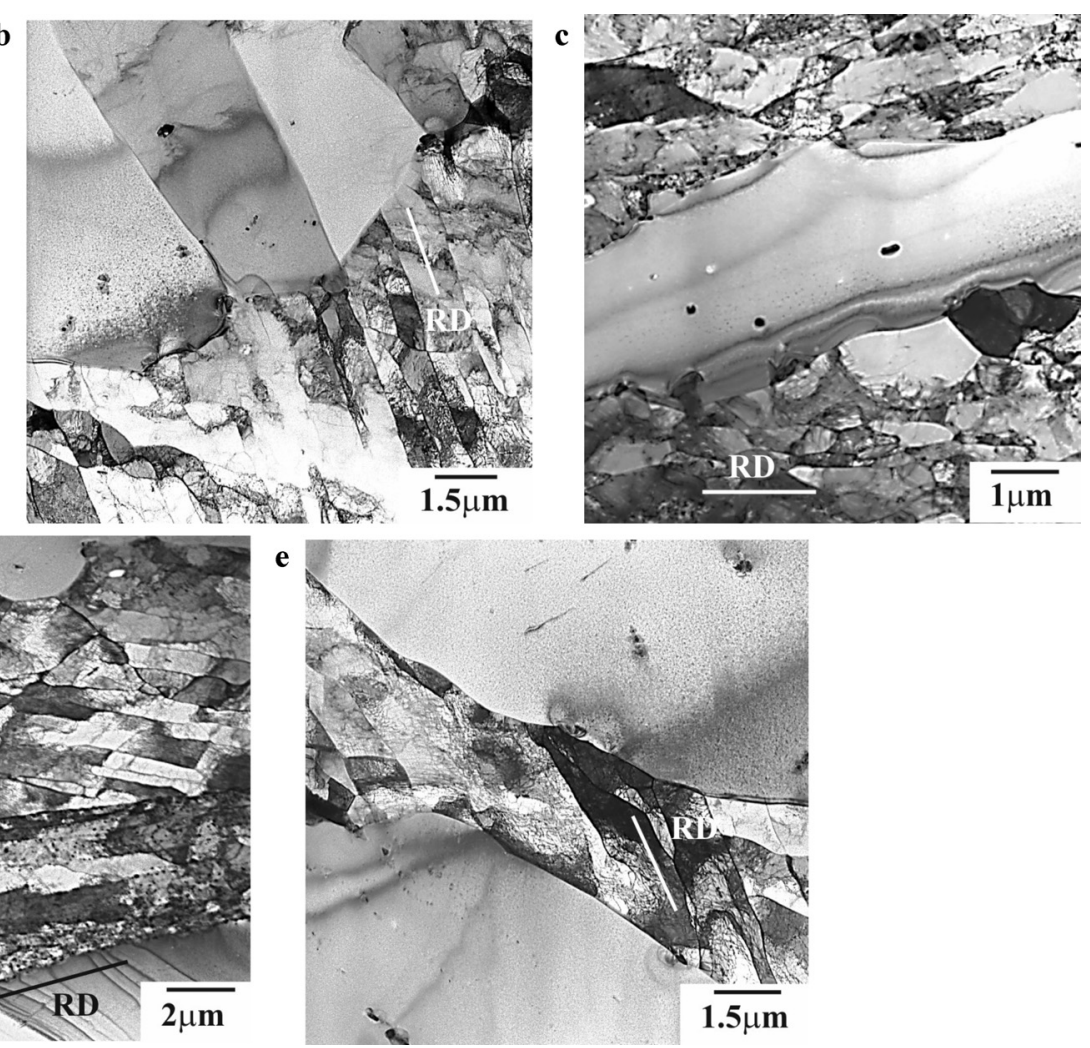

Fig. 7. Bright field micrographs of recrystallised grains in (a) the ELC steel after $60 \mathrm{~s}$ of annealing (zone axis for the recrystallised grain is $[001]_{\mathrm{RG}}$, for the microbands $\left.[111]_{\alpha}\right)$, (b) the $\mathrm{LC}(\mathrm{Cr}, \mathrm{B})$ and (c) $\mathrm{LC}(\mathrm{Cr})$ steels after $180 \mathrm{~s}$ of annealing, (d) the $\mathrm{LC}(\mathrm{Cr}, \mathrm{P})$ steel after $240 \mathrm{~s}$ of annealing and (e) the $\mathrm{LC}(\mathrm{Cr})$ steel after $300 \mathrm{~s}$ of annealing. 

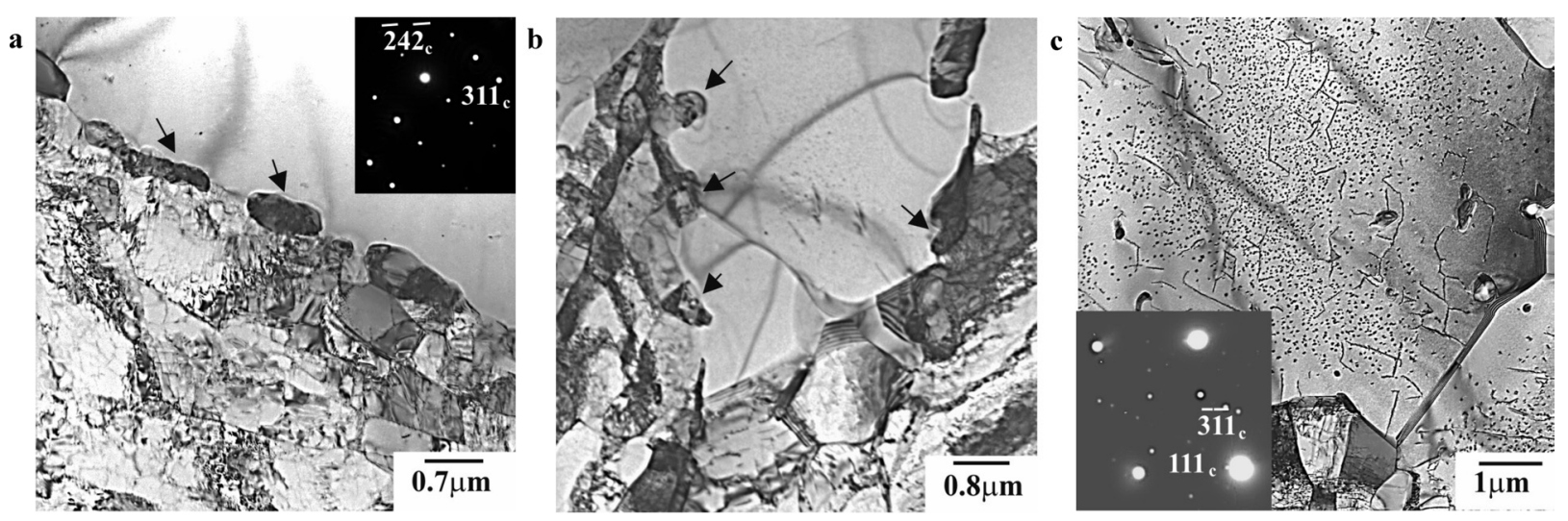

Fig. 8. Bright field micrographs of carbides in the $\mathrm{LC}(\mathrm{Cr})(\mathrm{a}$ and c) and $\mathrm{LC}(\mathrm{Cr}, \mathrm{P})(\mathrm{b})$ steels after $300 \mathrm{~s}$ of annealing: (a, b) $\mathrm{Cr}_{23} \mathrm{C}_{6}$ coarse carbides (zone axis for (a) is $[\overline{3} 27]_{\mathrm{c}}$ ), (c) $\mathrm{Cr}_{23} \mathrm{C}_{6}$ strain-induced carbides (zone axis of the recrystallised grain is $[123]_{\alpha}$, of carbides $\left.[2 \overline{4} 2]_{c}\right)$.
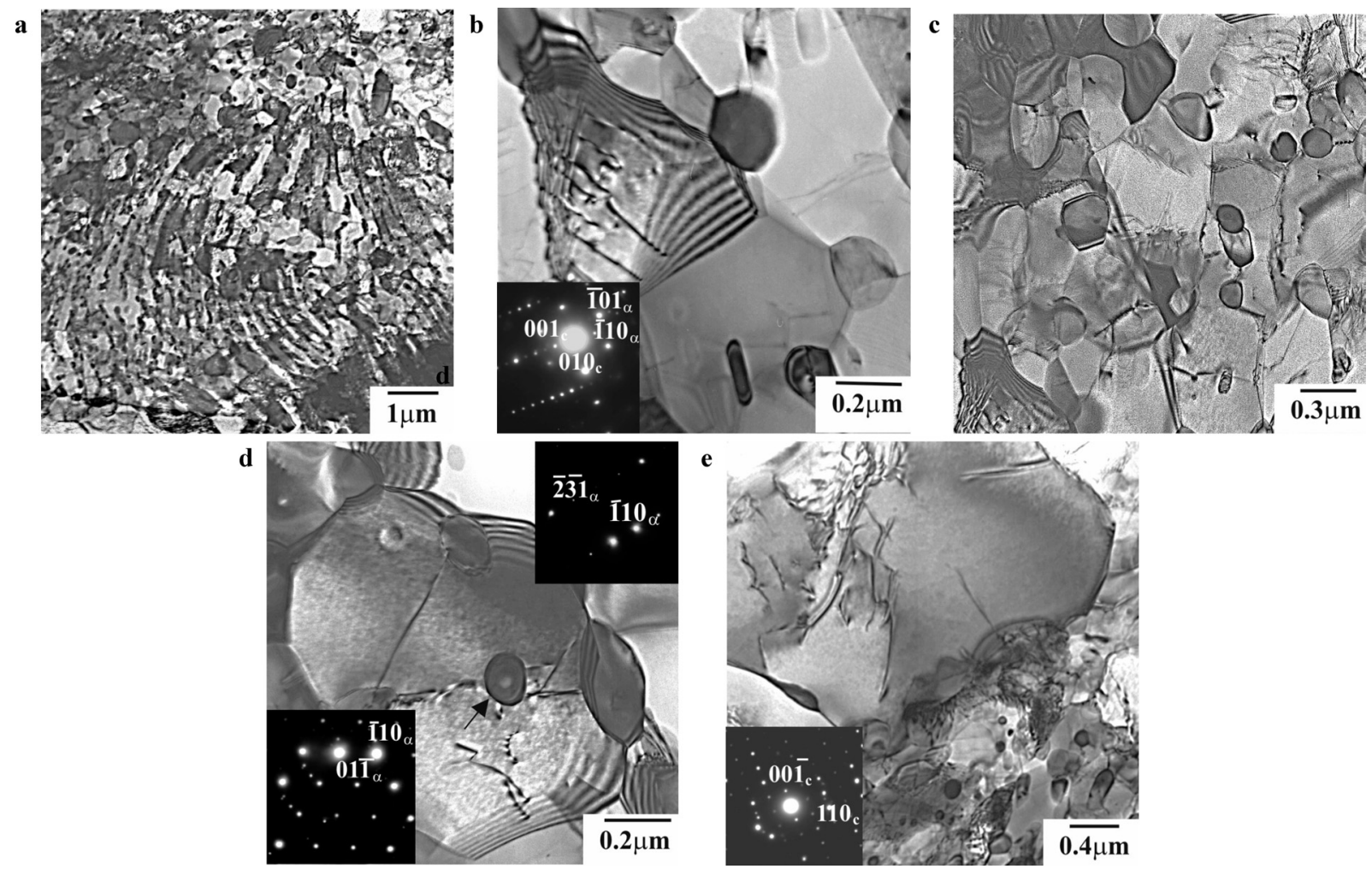

Fig. 9. TEM micrographs of pearlite in the $\operatorname{LC}(\mathrm{Cr})(\mathrm{a}, \mathrm{b}, \mathrm{c})$ and $\mathrm{LC}(\mathrm{Cr}, \mathrm{B})(\mathrm{d}, \mathrm{e})$ steels after $180 \mathrm{~s}(\mathrm{a}, \mathrm{b}, \mathrm{c}, \mathrm{d})$ and $300 \mathrm{~s}(\mathrm{e})$ of annealing: (a) general view of pearlite decomposition, (b) new grain (zone axis is $[111]_{\alpha}$ ) nucleating at carbide (zone axis is $[100]_{c}$ ), (c) acceleration of nucleation in pearlite area, (d) new grain (zone axis is $[111]_{\alpha}$ ) nucleating at carbide (zone axis is $[100]_{\mathcal{c}}$ ) within another grain (zone axis is $[115]_{\alpha}$, top diffraction) and (e) recrystallised grain formed in pearlite area (zone axis of carbide is $\left.[\overline{1} 10]_{c}\right)$.

driving force for recrystallisation.

This can explain the results obtained in the previous study $^{20)}$ in which shear bands were preferred over grain boundaries as nucleation sites. An increase in annealing time led to the formation of a cell structure within the parallelogram structure followed by the formation of subgrains i.e. of structures of lower energy. These subgrains displayed a wide range of boundary misorientations from low to high, while lower values of misorientation were associated with the subgrains formed at the microbands. Here an increase in misorientation level was linked to the additional dislocation density present in the parallelogram structure.

In contrast to the grains with parallelogram structures, the recovery process in the grains containing only microbands followed the standard series of micromechanisms, i.e. cell formation, annihilation of dislocations within the cells, subgrain formation, subgrain growth and coalescence. In this case, recovery was more sluggish than in the grains containing shear bands.

The TEM study did not reveal the presence of grains with shear bands in the ELC steel after warm rolling. As reported by Barnett, ${ }^{7)}$ a small number of grains with shear bands in the deformed material leads to a weak $\{111\}$ recrystallisation component and a low mean $r$ value in the annealed material. The difference in the recovery behavior of grains with and without shear bands clearly affects the later 
recrystallisation process and the final recrystallisation texture.

Two different types of carbides were present in the alloyed steels after warm rolling: (i) coarse and (ii) fine strain-induced carbides. Both types influence the recovery process during annealing. The coarse chromium carbides were located at microbands, shear band and subgrain boundaries. These carbides increased their sizes and volume fractions during annealing and became spherical. The subgrains grew during recovery by the migration of low angle boundaries. The carbides present at the sub-boundaries prevented this movement. Thus, the presence of carbides decreases the sub-boundary mobility and retards recovery.

The strain-induced particles were located within the microbands and at the microband boundaries. These particles pinned the dislocations within the microbands restraining their mobility and rearrangement during cell formation. This inhibited the formation of subgrains and retarded the recovery kinetics. The $\mathrm{LC}(\mathrm{Cr})$ steel displayed the highest volume fraction of particles within the microbands after warm rolling. This not only increased the precipitation hardening of the matrix and removed carbon from solution, but also influenced the recovery process by increasing the tendency for the dislocations to be pinned.

\subsection{Formation and Morphology of the Recrystallised Grains}

Recrystallised grains were present in the ELC steel after $60 \mathrm{~s}$ of annealing, while the alloyed steels displayed considerably more sluggish recrystallisation kinetics i.e., recrystallised grains were only observed after $180 \mathrm{~s}$. Ferrite has relatively high stacking fault energy so that recovery and recrystallisation are fairly rapid in unalloyed grades such as the ELC steel. By contrast, the solute elements present in the alloyed steels retard recovery through solute drag effects and in this way also retard recrystallisation. The recrystallised grains formed in the alloyed steels were oriented along the microbands or shear band clusters, while the new grains in the ELC steel were generally equiaxed. The shapes of the grains in the alloyed steels can be attributed to the presence of particles on microbands and shear band boundaries; these retarded sub-boundary migration during recovery and led to oriented grain growth during recrystallisation. This interpretation is supported by the fact that the microbands in the ELC steel increased their thicknesses during the early stages of annealing, while the thicknesses of the microbands in the alloyed steels remained constant.

The recrystallised grains inherited both the strain-induced particles found within the microbands after warm rolling as well as the coarse carbides present between the microbands or shear bands. When the moving grain boundaries captured some of the coarse carbides, the latter retarded further growth of these grains. This probably influenced the final texture by preventing grain reorientation during annealing.

\subsection{Nucleation of Recrystallised Grains on the Parti- cles}

The formation of coarse chromium carbides and the decomposition of pearlite accompanied by the formation of spherical $\mathrm{Fe}_{3} \mathrm{C}$ particles accelerated the progress of recrystallisation. These carbides acted as the source of particlestimulated nucleation of recrystallisation due to the formation of deformation zones with local lattice rotations close to these carbides after warm rolling. ${ }^{19)}$

The carbides can also stimulate a simultaneous nucleation of two new grains. However, some of these nuclei displayed a different growth rate and size.

\section{Conclusions}

The processes of recovery and recrystallisation were studied during the early stages of annealing in warm rolled low carbon steels. One was an unalloyed extra low carbon $(0.02 \mathrm{wt} \% \mathrm{C})$ ELC grade in commercial production. The other three all contained $0.5 \mathrm{wt} \%$ chromium and were prepared in the laboratory. One was modified with a $0.04 \mathrm{wt} \%$ phosphorus addition and another with a $0.005 \mathrm{wt} \%$ boron addition. It was found that:

(1) The presence of shear bands within certain grains after warm rolling led to the formation of a parallelogram structure and to a subsequent increase in subgrain misorientation during recovery.

(2) The parallelogram structure thus provides preferential nucleation sites.

(3) The addition of alloying elements stimulates the formation of both coarse and fine (strain-induced) carbides. The carbides can, on the one hand, accelerate recovery and recrystallisation by promoting the nucleation of new grains. On the other hand, they can hinder recrystallisation by retarding the migration of both low and high angle boundaries.

(4) The decomposition of pearlite accompanied by the formation of coarse spherical $\mathrm{Fe}_{3} \mathrm{C}$ carbides accelerate recrystallisation in their area.

\section{Acknowledgments}

The authors are grateful to the Australian Research Council and the Natural Sciences and Engineering Research Council of Canada for financial support and to Stelco Inc. and Dofasco Inc. of Hamilton, Canada for supplying the steels.

\section{REFERENCES}

1) P. Harlet, F. Beco, P. Cantinieaux, D. Bouquegneau, P. Messien and J. C. Herman: Int. Symp. on Low C Steels for the 90's, ed by R. Asfahani and G. Tither, TMS-AIME, Warrendale, PA, (1993), 389.

2) J. J. Jonas: Proc. Processing and Manufacturing of Advanced Materials, THERMEC '2000, ed. by T. Chandra, K. Higashi, C. Suryanarayana and C. Tome, Elsevier Science, U.K., (2000), 293.

3) M. R. Barnett and J. J. Jonas: ISIJ Int., 39 (1999), 856.

$4)$ R. K. Ray, J. J. Jonas and R. E. Hook: Int. Mater. Rev., 39 (1995), 129.

5) M. R. Barnett and J. J. Jonas: ISIJ Int., 37 (1997), 706.

6) A. S. Malin and M. Hatherly: Met. Sci., (1979), 463.

7) M. R. Barnett: Proc. Materials '98, ed. by M. Ferry, IMEA, Wollongong, Australia, (1998), 167.

8) A. S. Keh, Y. Nakada and W. C. Leslie: Dislocation Dynamics, ed. by A. R. Rosenfield, G. T. Hahn, A. L. Bement and R. I. Jaffee, McGraw-Hill, New York, (1967), 381.

9) A. Karimi Taheri, T. M. Maccagno and J. J. Jonas: ISIJ Int., 35 (1995), 1532.

10) M. R. Toroghinejad, A. O. Humphreys, D. Liu, F. Ashrafizadeh, A. Najafizadeh and J. J. Jonas: Metall. Mater. Trans. A, 34A (2003), 
ISIJ International, Vol. 45 (2005), No. 6

1163.

11) P. Messien and V. Leroy: Steel Res., 60 (1989), 320.

12) A. O. Humphreys, D. S. Liu, M. R. Toroghinezhad and J. J. Jonas: ISIJ Int., 42 (2002), Supplement, S52.

13) I. B. Timokhina, A. I. Nosenkov, A. O. Humphreys, J. J. Jonas and E. V. Pereloma: ISIJ Int., 44 (2004), 717.

14) A. R. Jones and N. Hansen: Acta Metall., 29 (1981), 589.

15) F. J. Humphreys and H. M. Chan: Mater. Sci. Technol., 12 (1996), 143.

16) G. H. Akbari, C. M. Sellars and J. A. Whiteman: Mater. Sci.
Technol., 18 (2002), 885.

17) R. Pradhan and J. J. Battisti: Hot- and Cold-Rolled Sheet Steels, ed. by R. Pradhan, G. Ludkovsky, The Metallurgical Society, TMS, Warrendale, PA, (1988), 82.

18) A. Belyakov, R. Kaibyshev and T. Sakai: Metall. Mater. Trans. A, 29A (1998), 161.

19) F. J. Humphreys and M. Hatherly: Recrystallization and Related Annealing Phenomena, Pergamon, Oxford, (1996), 30.

20) E. V. Pereloma, I. B. Timokhina, A. I. Nosenkov and J. J. Jonas: Metallurgia 2004, 43 (2004), 4. 